\title{
PANDEMIC H1N1 influenza lessons from the SOUTHERN HEMISPHERE
}

\author{
M G Baker (michael.baker@otago.ac.nz)1, H Kelly², N Wilson ${ }^{1}$ \\ 1. University of Otago, Wellington, New Zealand \\ 2. Victoria Infectious Diseases Reference Laboratory, Melbourne, Australia
}

This article was published on 22 October 2009.

Citation style for this article: Baker MG, Kelly H, Wilson N. Pandemic H1N1 influenza lessons from the southern hemisphere. Euro Surveill. 2009;14(42):pii=19370. Available online: http://www.eurosurveillance.org/ViewArticle.aspx?ArticleId=19370

Early in the 2009 H1N1 influenza pandemic, an editorial in Eurosurveillance noted the importance of observing experience with this novel virus in the southern hemisphere during their usual winter influenza season [1]. This special issue of Eurosurveillance is a timely response to that call. It contains reports from the island of Réunion, South Africa, South America (Brazil, Peru), and Australia (New South Wales and Victoria). It also includes an overview of the effect of the pandemic on indigenous people. This editorial summarises some of the key findings from these papers, reviews features of pandemic $\mathrm{H} 1 \mathrm{~N} 1$ influenza epidemiology in these countries, and lists some potential lessons for the northern hemisphere (and possible future waves in the southern hemisphere).

\section{Important findings from the papers in this issue}

Investigators from Réunion Island (located near Madagascar in the Indian Ocean) [2] used data from multiple surveillance systems, including influenza-like illness (ILI) reports by sentinel practitioners, virological surveillance, surveillance of hospital emergency departments and intensive care units (ICUs), and fatal cases attributed to influenza $A(H 1 N 1) v$ infection. The introduction of the pandemic virus happened later than in other southern hemisphere countries with community transmission not documented until 23 July 2009. The pandemic virus became the predominant circulating influenza virus on Réunion within four weeks following its first detection.

The paper from South Africa provides one of the first reports on the pandemic from an African country [3]. It is based on a descriptive analysis of the national epidemiology of the H1N1 influenza pandemic, focussing on laboratory-confirmed cases and deaths. Surveillance included multiple systems and an expected shift in focus as the pandemic progressed. The final analysis was based on a large number of laboratory-confirmed cases $(12,331)$ including 91 deaths. Of particular note was the high proportion of fatal cases who were human immunodeficiency virus (HIV)-positive (53\% based on 17/32 tested, against a background HIV prevalence of $18 \%$ in $15-49$ year-old adults) and pregnant (56\%, based on 25/45 women of reproductive age).

Assessment of the pandemic in Brazil [4] was based on surveillance of notified influenza cases and later ILI cases with severe acute respiratory infection (SARI). Reflecting its large population, Brazil reported 34,506 cases of ILI with SARI, although only $16.7 \%$ were laboratory-confirmed as pandemic influenza. There were 1,567 recorded deaths among SARI cases, including
645 with confirmed pandemic influenza. The age distribution of cases (peaks in the under five year-olds and in adults 20-29 years, with lower rates in the over 60 year-olds) was similar to that seen in higher income countries such as Australia and New Zealand. Severe illness was associated with pregnancy and a range of co-morbidities (notably chronic lower respiratory and metabolic diseases). The authors also noted marked geographic variations with cases concentred in southern and south-eastern Brazil, regions with more temperate climates bordering other affected South American countries.

Description of the pandemic in Peru [5] was based on established sentinel ILI and virological surveillance of influenza, surveillance of SARI, acute respiratory infection (ARI) and pneumonia, and additional case and cluster investigation. Peru reported 8,381 confirmed cases including 143 fatalities. Most fatal cases (75.5\%) had an identified co-morbidity, notably metabolic, cardiovascular or respiratory disease.

This edition includes three separate reports from Australia. Investigators from New South Wales (NSW) [6] provide perhaps the most comprehensive description of the pandemic using multiple surveillance systems (including use of novel systems such as ambulance despatch data and web-based systems for capturing attendances at specialist influenza clinics and ICU utilisation). The pandemic there lasted 10 weeks and had a substantial impact on ICUs, with an increased risk of severe illness, including respiratory failure, in those aged between 35 and 60 years. As seen elsewhere, vulnerable groups included pregnant women, indigenous people (Aboriginal or Torres Strait Islanders), those with chronic respiratory disease, and those with morbid obesity. However, the general influenza-related mortality and overall mortality between April and September 2009 was lower than that seen during the same period in recent years.

Although commencing earlier, the pandemic in Victoria [7] followed a similar epidemic pattern to NSW, based on a general practitioner sentinel surveillance system and notifications of laboratory-confirmed influenza. Peak ILI rates were comparable in magnitude to several previous years. Understanding of the Victorian experience has been strengthened by an accompanying paper which estimates the reproduction number $(R)$ during the epidemic in that state[8]. After accounting for undetected transmission, the authors estimate $R$ at 1.6 (95\% credible interval: 1.5-1.8). 
The final paper is focussed on the impact of the pandemic on indigenous people, rather than on a specific geographic area [9]. From the southern hemisphere, this analysis included indigenous people in Brazil (Amerindians), Australia (Aborigines and Torres Straits Islanders), New Zealand (Māori and Pacific peoples), and the Pacific (Polynesians, Melanesians). It also included indigenous people in the northern hemisphere, notably in Canada and the United States. In all of these countries indigenous peoples experienced significantly elevated risks of serious infection, with

T A B L E

Key epidemiological features of the H1N1 influenza pandemic 2009 reported by selected southern hemisphere countries

\begin{tabular}{|c|c|c|c|c|c|c|c|c|c|}
\hline $\begin{array}{l}\text { Country } \\
\text { or state }\end{array}$ & $\begin{array}{l}\text { First } \\
\text { detection of } \\
\text { influenza } \\
\text { A(H1N1)v } \\
\text { [date] }\end{array}$ & $\begin{array}{l}\text { Established } \\
\text { community } \\
\text { transmission } \\
\text { [date] }\end{array}$ & $\begin{array}{l}\text { Pandemic } \\
\text { peak [date] }\end{array}$ & $\begin{array}{l}\text { Population } \\
\text { [N] }\end{array}$ & $\begin{array}{c}\text { Hospital } \\
\text { admissions } \\
{[\mathrm{N}]}\end{array}$ & $\begin{array}{l}\text { Cumulative } \\
\text { incidence of } \\
\text { hospitalisation } \\
\text { [per 100,000] }\end{array}$ & $\begin{array}{l}\text { Deaths } \\
{[N]}\end{array}$ & \begin{tabular}{|l|} 
Cumulative \\
incidence \\
of deaths \\
[per million \\
population]
\end{tabular} & Source \\
\hline \multicolumn{10}{|c|}{ Africa and Indian Ocean } \\
\hline $\begin{array}{l}\text { Réunion } \\
\text { Island }\end{array}$ & 5 July & 23 July & 24-30 August & 802,000 & 255 & 31.8 & 6 & 7.5 & $\begin{array}{l}\text { European Centre for Disease } \\
\text { Prevention and Control Daily } \\
\text { Update, } 1 \text { October } 2009\end{array}$ \\
\hline $\begin{array}{l}\text { South } \\
\text { Africa }\end{array}$ & 14 June & 15 July & 3-9 August & $49,052,489$ & NA & NA & 91 & 1.9 & $\begin{array}{c}\text { South African National Institute } \\
\text { for Communicable Disease, } 12 \\
\text { October } 2009\end{array}$ \\
\hline \multicolumn{10}{|c|}{ South America } \\
\hline Argentina & NA & NA & 22-28 June & $40,301,927$ & 11,086 & 27.5 & 580 & 14.4 & $\begin{array}{c}\text { Influenza Pandemica (H1N1) } 2009 . \\
\text { Republica Argentina, } 9 \text { October } \\
2009\end{array}$ \\
\hline Brazil & 7 May & 16 July & 3 August & $186,842,147$ & NA & NA & 899 & 4.8 & $\begin{array}{l}\text { PAHO Regional Update Pandemic } \\
\text { (H1N1) 2009, } 9 \text { October } 2009\end{array}$ \\
\hline Chile & 17 May & 26 May & $\begin{array}{l}11 \text { June (Los } \\
\text { Lagos) }\end{array}$ & $16,284,741$ & 1,585 & 9.7 & 134 & 8.2 & $\begin{array}{l}\text { PAHO Regional Update Pandemic } \\
\text { (H1N1) 2009, } 9 \text { October } 2009\end{array}$ \\
\hline Paraguay & NA & NA & NA & $6,349,000$ & 128 & 2.0 & 42 & 6.6 & $\begin{array}{l}\text { PAHO Regional Update Pandemic } \\
\text { (H1N1) 2009, } 9 \text { October } 2009\end{array}$ \\
\hline Peru & 9 May & NA & $\begin{array}{l}22 \text { June (Lima } \\
\text { y Callao) }\end{array}$ & $29,546,963$ & NA & NA & 153 & 5.2 & $\begin{array}{l}\text { PAHO Regional Update Pandemic } \\
\text { (H1N1) 2009, } 9 \text { October } 2009\end{array}$ \\
\hline Uruguay & NA & NA & NA & $3,494,382$ & NA & NA & 20 & 5.7 & $\begin{array}{l}\text { PAHO Regional Update Pandemic } \\
\text { (H1N1) 2009, } 9 \text { October } 2009\end{array}$ \\
\hline \multicolumn{10}{|l|}{ Oceania } \\
\hline Australia & 8 May & 4 June & 21 July & $21,262,641$ & 4,844 & 22.8 & 183 & 8.6 & $\begin{array}{c}\text { Australian Influenza Surveillance } \\
\text { Report No. 21, } 2 \text { October } 2009\end{array}$ \\
\hline - Victoria & 20 May & 4 June & 28 June & $5,402,600$ & 513 & 9.5 & 24 & 4.4 & $\begin{array}{c}\text { Victorian Influenza Report No. 24, } \\
\text { reference [8] }\end{array}$ \\
\hline - NSW & 21 May & 15 June & 17 July & $7,017,100$ & 1,267 & 18.1 & 51 & 7.3 & $\begin{array}{l}\text { NSW Health Influenza Epidemiology } \\
\text { Report } 1 \text { May to } 20 \text { September } 2009\end{array}$ \\
\hline Fiji & NA & NA & NA & 849,000 & NA & NA & 0 & 0 & $\begin{array}{c}\text { Pacific Public Health Surveillance } \\
\text { Network: Pandemic Influenza A / } \\
\text { H1N1 } 2009 \text { Surveillance, Report as } \\
\text { of } 21 \text { October } 2009\end{array}$ \\
\hline $\begin{array}{l}\text { French } \\
\text { Polynesia }\end{array}$ & NA & NA & NA & 264,000 & NA & NA & 7 & 26.5 & $\begin{array}{c}\text { Pacific Public Health Surveillance } \\
\text { Network: Pandemic Influenza A / } \\
\text { H1N1 } 2009 \text { Surveillance, Report as } \\
\text { of } 13 \text { October } 2009\end{array}$ \\
\hline $\begin{array}{l}\text { New } \\
\text { Caledonia }\end{array}$ & NA & NA & NA & 249,000 & NA & NA & 9 & 36.1 & $\begin{array}{l}\text { European Centre for Disease } \\
\text { Prevention and Control Daily } \\
\text { Update, } 1 \text { October } 2009\end{array}$ \\
\hline $\begin{array}{l}\text { New } \\
\text { Zealand }\end{array}$ & 25 April & 1-7 June & 6-12 July & 4,143,279 & 1,001 & 24.2 & 18 & 4.3 & $\begin{array}{l}\text { Influenza Weekly Update } 28 \\
\text { September-4 October } 2009\end{array}$ \\
\hline Samoa & NA & NA & NA & 179,000 & NA & NA & 2 & 11.2 & $\begin{array}{l}\text { Pacific Public Health Surveillance } \\
\text { Network: Pandemic Influenza A / } \\
\text { H1N1 } 2009 \text { Surveillance, Report as } \\
\text { of } 21 \text { October 2009 }\end{array}$ \\
\hline Tonga & NA & NA & NA & 104,000 & NA & NA & 1 & 9.6 & $\begin{array}{l}\text { Pacific Public Health Surveillance } \\
\text { Network: Pandemic Influenza A / } \\
\text { H1N1 } 2009 \text { Surveillance, Report as } \\
\text { of } 21 \text { October 2009 }\end{array}$ \\
\hline
\end{tabular}

NA: not readily available 
hospitalisation and mortality rates that were three to seven times higher than those reported for non-indigenous populations.

\section{The time course and impact of the pandemic in southern} hemisphere countries

The countries described in this issue of Eurosurveillance are located south of the equator and share the same winter season. Consequently the emergence of pandemic H1N1 influenza coincided with their peak period for seasonal influenza. Despite considerable geographical and demographical differences between them, the pandemic showed a surprisingly consistent pattern of infection across these countries. We have summarised some epidemiologic features of the H1N1 influenza pandemic in these countries (Table). For purposes of comparison, we have included data on several other large South American countries (Argentina, Chile, Paraguay, Uruguay,) and some of the larger Pacific Islands (New Caledonia, French Polynesia, Samoa, Fiji) for which data were readily available in the public domain.

Following its detection in Mexico in mid-March 2009, the epidemic spread rapidly to all southern hemisphere countries listed in the Table [10]. In these countries, the first reported identifications of introduced virus ranged from late April through to early July. Introduction of the virus was followed by a variable interval before local community transmission was confirmed (i.e. transmission from cases with no known history of overseas travel or contact with a person or group with a connection to an imported case). Community transmission was usually accompanied by a rapidly accelerating epidemic that peaked within two to six weeks. The pandemic virus swiftly replaced seasonal influenza viruses [11]. The epidemic decline, although rapid, was usually somewhat slower than the initial rise.

Rates of hospitalisations and deaths showed wide variability by country. Hospitalisation rates ranged from 2.0 to 31.8 per 100,000 population, and mortality rates ranged from 0 to 36.1 per million population.

\section{Consistent features of the pandemic in southern hemisphere countries}

Within larger countries there were often marked regional variations in influenza rates. Some regions lagged by a few days to a few weeks. At the end of the spread within the country, there were often large geographic variations in the reported incidence of infection and its outcomes (hospitalisation and mortality rates).

There were consistent patterns in those most likely to present with clinical illness, and particularly, those most likely to have poor outcomes of infection such as hospitalisation, ICU treatment, or death. IIIness rates tended to be highest in children under the age of five years, sometimes with a second peak in young adults, with uniformly low rates in older populations (60+ years). The downward shift in age was well illustrated in South Africa where the median age of pandemic $\mathrm{H} 1 \mathrm{~N} 1$ influenza cases was 16 years, compared with 27 years for seasonal influenza $A(H 1 N 1)$ in 2008.

Indigenous people were vulnerable to poor outcome from pandemic H1N1 influenza infection [9]. Other vulnerable groups were pregnant women (with ICU admission rates in Australasia about nine times higher than expected [12]), severely obese people (with ICU admission rates in Australasia for those with a body mass index (BMI) of $>35$ about five times higher than expected [12]), and those with asthma or other chronic respiratory disease (with ICU admission rates in Australasia more than twice as high as would be expected [12]). HIV infection appeared more common in fatal cases in South Africa than expected based on prevalence in the population [3].

Mortality from the pandemic appeared to be relatively low. Most countries reported mortality rates of less than one per 100,000 population. There is evidence from New South Wales that excess

\section{B o X}

Pandemic lessons from the southern hemisphere

1. Remain cautious. The 2009 H1N1 influenza pandemic demonstrated typical pandemic influenza behaviour in all southern hemisphere countries were it was detected, including relatively high infectiousness in some populations, rapid replacement of seasonal influenza viruses, and a downward shift in the age groups affected. A similar pattern can be expected during the northern hemisphere influenza season. This virus therefore deserves the caution due any new pandemic influenza virus that has capacity to evolve over time.

2. Consider the relatively low severity of this pandemic. The public health impact of this pandemic virus places it at the least severe end of the pandemic influenza scale (category 1 out of 5 on the Pandemic Severity Index [21]). The resources applied to the public health response, and messages from health authorities to the public, need to appropriately reflect this level of threat.

3. Protect vulnerable groups. Some groups have a much higher risk of poor outcomes, notably indigenous populations, pregnant women, and those with serious chronic health conditions (including respiratory and cardiovascular disease, diabetes, morbid obesity, and possibly HIV infection). Public health management should be focussed on protecting these groups.

4. Consider the limited role for containment. Containment measures now have only a limited role given the global distribution of pandemic H1N1 influenza. Border control measures could be considered for isolated populations, but even these are likely to be of limited value except in places with very low travel volumes [22].

5. Consider cost-effective mitigation measures. Public health measures to limit the spread of pandemic H1N1 influenza may have value in reducing the intensity of the pandemic peak once community transmission is established. Relatively low-cost measures such as promotion of hand and respiratory hygiene and home isolation of those who are ill, are likely to be the most defensible [23]. They may also provide co-benefits in terms of reducing transmission of other infectious diseases. More disruptive social distancing such as school closures seem difficult to justify terms of reducing transmission of other infectious
unless the severity of this pandemic increases.

6. Plan for the impact on health services. Pandemic influenza may strain healthcare services, particularly ICUs and emergency departments. This pressure may be most intense during a relatively short epidemic peak.

7. Optimise surveillance. Some surveillance methods are better than others at characterising the pandemic at all stages. Systems that appeared particularly valuable were established sentinel surveillance systems that combined virological and epidemiological data, systems that could rapidly report hospitalisations and deaths from influenza, and well organised networks of clinicians (notably ICU specialists) who were able to characterise particularly important sub-populations of cases. There is potential for greater use of more novel approaches (cross sectional telephone surveys of ILI, sero-surveys, and even use of Google Flu Trends [24 25]).

8. Plan research. Northern hemisphere countries are well placed to plan and conduct research to investigate important questions about pandemic influenza epidemiology, prevention and control. In particular, there is still a high level of uncertainty about the effectiveness of both pharmaceutical and non-pharmaceutical interventions for reducing the spread and impact of such pandemics. 
mortality from influenza and pneumonia over the period of the pandemic was less than in previous years [6]. These results suggest the case fatality ratio (CFR) was also low. The main limitation in estimating the CFR is uncertainty over the size of the infected denominator population [13]. A report from New Zealand estimated approximately $7.5 \%$ of the population had symptomatic illness, suggesting $10-15 \%$ may have been infected and a CFR of $<0.01 \%$ [14]. Samoa provides a dramatic illustration of the impact of this pandemic compared to the 1918-19 pandemic. At that time the islands (then named "Western Samoa") had the highest death rate for any country or territory, losing 19-22\% of its population [15]. In the current pandemic Samoa has recorded only two deaths, a mortality rate of $0.001 \%$ (Table).

The pandemic appears not to have overwhelmed health services in the southern hemisphere countries reviewed in this issue, although some services were at their maximum capacity. In Australia and New Zealand, ICU admissions due to confirmed infection with pandemic influenza were carefully tracked and reached a maximum of 8.9 to $19.0 \%$ of ICU capacity during the most intense weeks of the pandemic [12]. However, a report from Argentina suggested that the pandemic can threaten to overwhelm healthcare systems unless the public is given very clear messages about the appropriate use of these services [16].

Pandemic containment measures were inconsistently used in southern hemisphere countries and their impact remains uncertain. Border and cluster controls were reported by Australia (NSW [6] and Victoria [7]), New Zealand [14], Réunion Island [2] and Peru[5]). Both New Zealand and Réunion reported delays of several weeks from the first detection of imported cases to the establishment of community transmission. By contrast, investigators in Victoria suggested that community transmission of the pandemic virus may have been established prior to the commencement of testing [7].

Southern hemisphere countries used data from a range of surveillance systems. The most comprehensive appeared able to provide timely and sensitive information on general practice consultations, emergency department attendances, hospitalisations, ICU utilisation, and deaths from influenza and related diseases. Countries with fewer resources had correspondingly fewer sources of information. Surveillance in these settings tended to be orientated toward meeting the more minimal surveillance requirements of the World Health Organization (WHO) [17], which focus on early detection and investigation, comprehensive assessment, and monitoring of the pandemic.

\section{Areas of uncertainty and research needs}

The infectiousness of the pandemic virus (as measured by the reproduction number) and existing immunity in the population have not been fully characterised. The analysis from Victoria presented here [8], may help to explain one of the paradoxical findings of the pandemic in southern hemisphere countries: the observation of a rapid rise in the epidemic curve would suggest a fairly infectious virus, whereas the proportion of the population apparently infected appears relatively small [14]. The estimated reproduction numbers of 1.6 for Victoria was within the range of 1.37 reported for Peru [18] to 1.96 for New Zealand [19]. As the analysis for Victoria suggests, a single estimate of $R$ is inadequate to fully characterise the infectiousness of the virus. Their finding of higher infectiousness in children suggests an epidemic that was rapidly propagated in children, with some 'spillover' into adult populations. Combined with some pre-existing immunity in older age groups, this modelling would help to explain the observed epidemic pattern. Serological surveys will be useful to clarify these issues further.

It is too early to expect robust evaluations of the interventions used in southern hemisphere countries during the pandemic. The apparent success of border controls and cluster controls at delaying pandemic entry into some countries, such as New Zealand and Réunion, should be evaluated. The declining reproduction number observed in Victoria may reflect the effect of mitigation strategies such as reactive school closure, quarantine, antiviral treatment and prophylaxis and voluntary social distancing or may merely be a feature of the pandemic virus infecting an immunologically naïve population. Again, the effects of pharmaceutical treatment and social distancing measures need further evaluation. As has happened in Australia, we believe it is appropriate for national funding agencies to support both commissioned and investigatorled research, so that we can learn as much as possible from this pandemic [20].

There are lessons that European countries can potentially learn from the experience in the southern hemisphere with this pandemic (Box). High quality surveillance and research in the northern hemisphere also has the capacity to reduce the considerable uncertainty that remains around the behaviour of this new pandemic virus.

\section{Acknowledgements}

We thank Kristina Grant, Surveillance Data Manager and Research Assistant, Victorian Infectious Diseases Reference Laboratory, Australia for assistance with preparing Table 1.

\section{References}

1. Depoortere E, Mantero J, Lenglet A, Kreidl P, Coulombier D. Influenza A(H1N1) $V$ in the southern hemisphere--lessons to learn for Europe? Euro Surveill 2009;14(24):pii=19246. Available from: http://www.eurosurveillance.org/ ViewArticle.aspx?ArticleId $=19246$

2. Thouillot F, Do C, Balleydier E, Rachou E, Staikowsky F, Morbidelli P, et al. Preliminary analysis of the pandemic H1N1 influenza on Réunion Island (Indian Ocean): surveillance trends (July to mid-September 2009). Euro Surveill. 2009;14(42):pii=19364. Available from: http://www.eurosurveillance. org/ViewArticle.aspx?ArticleId=19364

3. Archer BN, Cohen C, Naidoo D, Thomas J, Makunga C, Blumberg L, et al. Interim report on pandemic H1N1 influenza virus infections in South Africa, April to October 2009: Epidemiology and factors associated with fatal cases. Euro Surveill. 2009;14(42):pij=19369. Available from: http://www.eurosurveillance. org/ViewArticle.aspx?ArticleId=19369

4. Oliveira WK, Hage EC, Penna GO, Kuchenbecker RS, Santos HB, Araujo WN, et al Pandemic H1N1 influenza in Brazil: Analysis of the first 34,506 notified cases of influenza-like illness with severe acute respiratory infection (SARI). Euro Surveill. 2009;14(42):pii=19362. Available from: http://www.eurosurveillance. org/ViewArticle.aspx?ArticleId=19362

5. Gómez J, Munayco CV, Arrasco JC, Suarez L, Laguna-Torres VA, P.V. A, et al. Pandemic influenza in a southern hemisphere setting: Peru. The experience from May to September, 2009. Euro Surveill. 2009;14(42):pij=19371. Available from: http://www.eurosurveillance.org/ViewArticle.aspx?ArticleId=19371

6. New South Wales public health network. Progression and impact of the first winter wave of the 2009 pandemic H1N1 influenza in New South Wales, Australia. Euro Surveill, 2009:14(42):pij=19365. Available from: http://www. eurosurveillance.org/ViewArticle.aspx?ArticleId=19365

7. Fielding JE, Higgins N, Gregory JE, Grant KA, Catton MG, Bergeri I, et al. Pandemic H1N1 influenza surveillance in Victoria, Australia, April-September, 2009. Euro Surveill. 2009;14(42):pij=19368. Available from: http://www. eurosurveillance.org/ViewArticle.aspx?ArticleId=19368

8. McBryde ES, Bergeri I, van Gemert C, Rotty J, Headley EJ, Simpson K, et al. Early transmission characteristics of influenza $A(\mathrm{H} 1 \mathrm{~N} 1) \mathrm{v}$ in Australia: Victorian state, 16 May - 3 June 2009. Euro Surveill. 2009;14(42):pii=19363. Available from: http://www.eurosurveillance.org/ViewArticle.aspx?ArticleId=19363 
9. La Ruche G, Tarantola A, Barboza P, Vaillant L, Gueguen J, Gastellu-Etchegorry M, et al. The 2009 pandemic H1N1 influenza and indigenous populations of the Americas and the Pacific. Euro Surveill. 2009;14(42):pii=19366. Available from: http://www.eurosurveillance.org/ViewArticle.aspx?ArticleId=19366

10. Centers for Disease Control and Prevention (CDC). Outbreak of swine-origin influenza A (H1N1) virus infection - Mexico, March-April 2009. MMWR Morb Mortal Wkly Rep. 2009;58(17):467-70.

11. Centers for Disease Control and Prevention (CDC). Surveillance for the 2009 pandemic influenza A (H1N1) virus and seasonal influenza viruses - New Zealand, 2009. MMWR Morb Mortal Wkly Rep. 2009;58(33):918-21.

12. The ANZIC Influenza Investigators. Critical Care Services and 2009 H1N1 Influenza in Australia and New Zealand. N Engl J Med. 2009. [Epub ahead of print].

13. Wilson N, Baker MG. The emerging influenza pandemic: estimating the case fatality ratio. Euro Surveill 2009;14(26):pii=19255. Available from: http://www. eurosurveillance.org/ViewArticle. aspx?ArticleId=19255

14. Baker MG, Wilson N, Huang QS, Paine S, Lopez L, Bandaranayake D, et al. Pandemic influenza $A(H 1 N 1) v$ in New Zealand: the experience from April to August 2009. Euro Surveill. 2009;14(34):pii=19319. Available from: http://www. eurosurveillance.org/ViewArticle.aspx?ArticleId $=19319$

15. McLeod MA, Baker M, Wilson N, Kelly H, Kiedrzynski T, Kool JL. Protective effect of maritime quarantine in South Pacific jurisdictions, 1918-19 influenza pandemic. Emerg Infect Dis. 2008;14(3):468-70.

16. Petherick A. Flu furore hits Argentina. Nature. 2009;460(7253):311.

17. World Health Organization (WHO). Global Surveillance during an Influenza Pandemic. Geneva: WHO. 2009. Available from: http://www.who.int/csr/disease/ swineflu/global_pandemic_influenza_surveilance_apr09.pdf

18. Munayco C, Góomez J, Laguna-Torres V, Arrasco J, Kochel TJ, Fiestas V, et al. Epidemiological and transmissibility analysis of influenza $A(\mathrm{H} 1 \mathrm{~N} 1) \mathrm{v}$ in a southern hemisphere setting: Peru. Euro Surveill. 2009;14(32):pii=19299. Available from: http://www.eurosurveillance.org/ViewArticle. aspx?ArticleId $=19299$

19. Nishiura H, Wilson N, Baker MG. Estimating the reproduction number of the novel influenza A virus (H1N1) in a Southern Hemisphere setting: preliminary estimate in New Zealand. N Z Med J. 2009;122(1299):73-7.

20. Wilson N, Baker M, Jennings L, Murdoch D, Krause K, Edwards R, et al. A design fault in New Zealand's health research funding system exposed by pandemic influenza. N Z Med J. 2009;122(1304):121-2.

21. Centers for Disease Control and Prevention (CDC). Community strategy for pandemic influenza mitigation. CDC. 2007. Available from: http://www.flu.gov/ professional/community/commitigation.html\#IV

22. Eichner M, Schwehm M, Witson N, Baker MG. Small islands and pandemic influenza: potential benefits and limitations of travel volume reduction as a border control measure. BMC Infect Dis. 2009;9:160.

23. Jefferson T, Del Mar C, Dooley L, Ferroni E, Al-Ansary LA, Bawazeer GA, et al. Physical interventions to interrupt or reduce the spread of respiratory viruses: systematic review. BMJ. 2009;339.

24. Ginsberg J, Mohebbi MH, Patel RS, Brammer L, Smolinski MS, Brilliant L. Detecting influenza epidemics using search engine query data. Nature. 2009;457(7232):1012-4.

25. Eurosurveillance editorial team. Google flu trends includes 14 European countries. Euro Surveill. 2009;14(40):pii=19352. Available from: http://www. eurosurveillance.org/ViewArticle.aspx?ArticleId=19352 